\title{
Haemoglobinopathy prevention program in Turkey
}

\author{
D. Canatan
}

\author{
President of Thalassemia Federation of Turkey, President of Akdeniz Kan Hastaliklari Vakfi \\ Antalya, Turkey
}

\begin{abstract}
Thalassemia and abnormal haemoglobins are a serious health problem in Turkey. Very important steps for toward preventing thalassemia have been taken in Turkey by Ministry of Health ( $\mathrm{MOH})$, Turkish National Haemoglobinopathy Council (TNHC) and Thalassemia Federation of Turkey (TFT) since 2000. In 1993, a law was issued called Fight Against Hereditary Blood Disease especially for thalassemia and haemoglobinopathies. The law commends to prevent haemoglobinopathies and to treat all patients with haemoglobinopathy and thalassemia. A pilot project was started and centres were created in the MOH Hospitals in the southern provinces of Turkey. In 2000, TNHC was installed to combine all centres, foundations, and associations into one organization controlled by the $\mathrm{MOH}$. In 2001, the $\mathrm{MOH}$ and the TNHC made an inventory of all recorded patients with thalassemia and abnormal hemoglobins in Turkey, registering at least 4513 patients. In 2002, written regulations for the Fight Against Hereditary Blood Disease were published. MOH and TNHC selected 33 provinces situated in the Thrace, Marmara, Aegean, Mediterranean and South Eastern regions with high birth prevalence of severe haemoglobinopathies. In 2003, the haemoglobinopathy scientific committee was set-up, a guidebook was published and a national Hemoglobinopaty Prevention Program (HPP) was started in these high risk provinces . This program is running in these provinces successfully. In 2005, TFT was established as a secular society organization instead of TNHC. In 2007, National Thalassemia Prevention Campaign (NTPC) was organized for public education by TFT. This campaign contributed very important supporting to HPP in Turkey, because totally 62.682 people such as health workers, students, teachers, demarches, religion offi-
\end{abstract}

\footnotetext{
Correspondence: D. Canatan, MD, President of Thalassemia Federation of Turkey, President of Akdeniz Kan Hastaliklari Vakfi, Antalya, Turkey. Tel./Fax: +90.242.2432020-21. E-mail: dcanatan@superonline.com www.talasemifederasyonu.org.tr - www.akhav.org.tr

Key words: haemoglobinopathy prevention program, Turkey.

(C) Copyright D. Canatan, 2011

Licensee PAGEPress, Italy

Thalassemia Reports 2011; 1(s2):e4

doi:10.4081/thal.2011.s2.e4
}

This article is distributed under the terms of the Creative Commons Attribution Noncommercial License (by-nc 3.0) which permits any noncommercial use, distribution, and reproduction in any medium, provided the original author(s) and source are credited.

Parts of this work were presented at the "12th International Conference on Thalassemia and Hemoglobinopathies", Antalya (Turkey), 11-14 May 2011. cers and the other many people were educated for preventing thalassemia and haemoglobinopathies. In 2009, National Thalassemia Education Seminars (NTES) for health personnel have been planned in 26 cities by $\mathrm{MOH}$ and TFT. A total 3.600 health persons were educated on thalassemia prevention and therapy with NTES in 18 centres in 2009 and 2010. In conclusion, according to reports of MOH, 46 first level haemoglobinopathy diagnosis centres, 5 second level diagnosis and therapy centre and 5 third level prenatal diagnosis centre were setup and licenced in 30 cities between 2003 and 2009. While premarital screening tests were $30 \%$ of all couples in 2003 , it increased continuously during 6 years and it reached $81 \%$ in 2008 . The number of new born with thalassemias and hemoglobinopathies was 272 in 2002, it was decreased to 23 in 2008, as a result there has been an $90 \%$ reduction in new affected births.

\section{Background}

In 1958, the first clinical and hematological studies on thalassemia and haemoglobinopathies in Turkey was published by Aksoy et al [1]. In 1971, Çavdar and Arcasoy reported that overall incidence of $\beta$-thalassemia in Turkey was $2.1 \% .{ }^{2}$ In 1983 , first prenatal diagnostic procedures for identifying haemoglobinopathies were performed by Altay $e t$ $a l .{ }^{3}$ In 1987, Akar et al. showed that the most frequent thalassaemia allele in the Turkish population was the IVS-1 nt 110 mutation, which was the most common thalassaemia mutation in the majority of the high risk regions of the Mediterranean area. ${ }^{4}$ In 1992, Başak et al. reported the spectrum of $\beta$-thalassemia mutations occuring in the Turkish population..$^{5}$ In 1993, a law was issued called Fight Against Hereditary Blood Disease a pilot Project was started and centres for Research and Treatment for Hereditary Blood Disease were created in the Ministry of Health (MOH) Hospitals in the south provinces of Turkey, Antalya, Antakya, Mersin, Mugla regions. In 2000, Turkish National Hemoglobinopathy Council (TNHC) was installed to combine all centres, foundations and associations into one organization controlled by the MOH. In 2001, the MOH and the TNHC made an inventory of all recorded patients with thalassemia and abnormal haemoglobins in Turkey. ${ }^{6-8}$ In 2002, Altay published that screening studies for abnormal haemoglobins and $\beta$-thalassemia during the last 40 years. These studies revealed most common abnormal haemoglobin was $\mathrm{HbS}$ followed by $\mathrm{Hb} \mathrm{D}, \mathrm{HbE}$, and $\mathrm{Hb} \mathrm{O}$ Arab. In addition 42 abnormal haemoglobins were identified in Turkish population. ${ }^{9}$ In 2002, written regulations for the Fight Against Hereditary Blood Disease (FAHBD) were published. $\mathrm{MOH}$ and TNHC selected 33 provinces situated in the Thrace, Marmara, Aegean, Mediterranean and South Eastern regions with high birth prevalence of severe haemoglobinopathies. Haemoglobinopaty Prevention Program (HPP) was started in these high risk provinces on the 8th of May, 2003..$^{6-8}$

The aims of HPP are following up: i) to assess the present situation in each region by recording patients and carrier, ii) to produce a 
detailed prevalence and incidence map showing the situation in Turkey, iii) to establish reference centres for prevention and state of the art therapy, iv) to educate the healthcare personnel to provide education, information to the public, as well as screening and genetic counselling, v) to inform the public at large about thalassemia and haemoglobinopathy using press media and associations for public education. vi) to screen the carriers in high prevalence areas to diagnose the trait and to offer partner and family analysis and genetic counselling to couples at risk. ${ }^{6-8}$

\section{Materials and Methods}

The General Director of the Mother and Child Health / Family Planning of the MOH was responsible for national HPP depends on the written regulations of the FAHBD. According to FAHBD plans, the project included three levels. First Level (Diagnosis and Screening Centres); new reference centres were created for public education, screening and genetic counselling and existing centres were officially licensed. Second Level (Diagnosis and Therapy Centres); these centres were created for state of the art treatment after the diagnosis is established for the diagnosis, therapy and follow-up of patients with thalassemia and haemoglobinopathies. Third Level (Prenatal diagnosis, mutation analysis or bone marrow transplant centres); the existing centres at university hospital had to be licenced according to the special regulations. The General Director of the Treatment Service of the $\mathrm{MOH}$ was responsible for therapy. In this way, both directors were working in a coordinated way with the TNHC. A public health manager in each city coordinate this project and organize a team for education, screening, genetic counselling and the records of all patients and carriers on regular basis. ${ }^{6}$

Thalassemia Federation of Turkey (TFT) was established as a secular society organization instead of TNHC in 2005. Thalassemia Federation have defined the following objectives: i) To speak with one voice at all national and international conventions and gatherings, ii) To find solutions for the problems of haemoglobinopathy patients, their families and haemoglobinopathy centers iii) To determine standard procedures for prevention and treatment of haemoglobinopathy. ${ }^{7}$

National Thalassemia Prevention Campaign (NTPC) was organized for public education and supporting of HPP was started by MOH and TFT in 2007.

National Thalassemia Education Seminars (NTES) for health personnel have been planned by MOH and TF in 26 cities in 2009 .

\section{Results}

The $\mathrm{MOH}$ and the TNHC picked up the results of screening from 16 different cities on the Turkish Mediterranean coastal areas and western regions around the Aegean Sea and Marmara Sea made between 1995 and 2000. In total 377.339 healthy subjects were screened, yielding an average frequency of $\beta$-thalassemia trait was $4.3 \%$. The highest prevalence of $\beta$-thalassemia trait (13.1\%) was found in Antalya region and $\mathrm{HbS}$ trait (10\%) was found in the Çukurova region. ${ }^{6}$

The $\mathrm{MOH}$ and the TNHC made a registry of all recorded patients with thalassemia and abnormal haemoglobins in Turkey, registering at least 4513 patients. The classification of these patients was $2567 \beta$ thalassemia major, 1050 Sickle Cell Disease(SCD), $700 \beta$ thalassemia intermedia , and 196 cases in various combinations with other abnormal haemoglobins in $2001 .^{6}$

Thalassemia Federation authority committee arranged an assembly with Ministry of the Health, Ministry of the Internal Affairs, Ministry of Education, Ministry of Religion to take support of whole official foundations for the NTCP. After an academic committee prepared master slides for public and health workers' education programs. A long vehicle Talotir was specially designed as an education hall and symbolically represented the National Prevention Campaign. A total 23 cities in Thrace, Western and Southern Anatolia with high incidence of thalassemia were chosen for program. Target population of education were mainly doctors, other health staff, teachers, students, demarches, religion officers, patients, their families in addition to public. This campaign contributed very important supporting to HPP in Turkey, because totally 62.682 people such as health workers, students, teachers, demarches, religion officers and the other many people were educated for preventing thalassemia and haemoglobinopathies. ${ }^{10}$

A total 3600 health persons were educated on thalassemia prevention and therapy by NTES in 18 centres in 2009 and 2010.

According to reports of $\mathrm{MOH}, 46$ first level haemoglobinopathy diagnostic centers, 5 second level diagnosis and therapy centre and 5 third level prenatal diagnosis centre were licenced in 30 cities between 2003 and 2009 . While premarital screening tests were $30 \%$ of all couples in 2003, it was increased continuously between 2003 and 2008 and it was reached $81 \% .{ }^{8}$ (Figure 1).

The number of new born with thalassemia and haemoglobinopathies was 272 in 2002, it was decreased to 23 in 2008 , as a result there has been an $90 \%$ reduction in new affected births. ${ }^{8}$ (Figure 2 ).

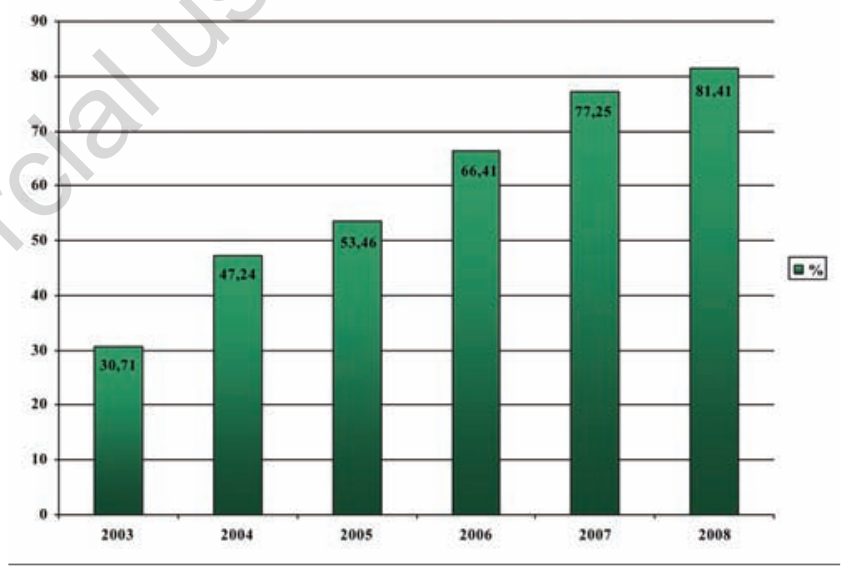

Figure 1. The percentage of premarital screening thalassemia test in couples. 8

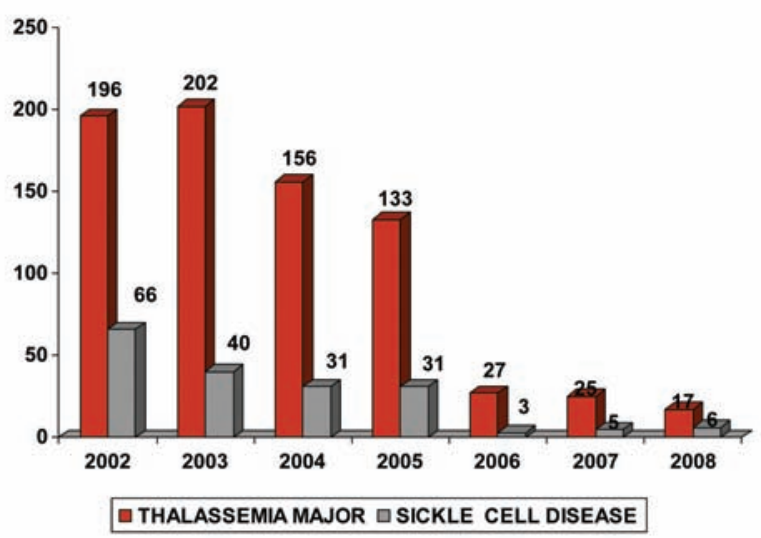

Figure 2. The number of new born with thalassemias and hemoglobinopathies. ${ }^{8}$ 


\section{Discussion}

Thalassemia and abnormal haemoglobins are a serious health problem in the all word. It is estimated that in excess of 300,000 children are born each year with a severe inherited disorder of haemoglobin and that approximately $80 \%$ of these births occur in low- or middle-income countries. ${ }^{11}$ World Health Organization (WHO) ${ }^{12}$ started first studies on prevention of thalassemia in Mediterranean countries in 1970's. WHO guidelines for the control haemaoglobin disorders includes optimal management for patients, community-based prevention education, prospective heterozygote screening programs, genetic counselling and prenatal diagnosis services based on an integrated strategy definitions. ${ }^{13}$

Prevention strategies for severe haemoglobinopathies changes in endemic and nonendemic immigration countries such as the Latium example. ${ }^{14}$ Thalassaemia carrier screening programmes provide a unique opportunity to compare the delivery of carrier screening programmes carried out in different cultural, religious and social contexts. The manner in which thalassaemia carrier screening programmes are structured among different populations varies greatly in several aspects, including whether the programmes are mandatory or voluntary, the education and counselling provided and whether screening is offered pre-pregnancy or antenatal. ${ }^{15}$

Thalassemia and haemoglobinopathies are very important health problem in Turkey. After regulations for the FAHBD published, a national HPP was started in selected 33 provinces situated in the Thrace, Marmara, Aegean, Mediterranean and South Eastern regions with high incidence of severe haemoglobinopathies by MOH and TNHC on the $8^{\text {th }}$ of May, 2003. New diagnostic centres were created for public education, premarital screening tests and genetic counselling. ${ }^{8}$ NTCP contributed very important supporting to HPP in Turkey, because totally 62.682 people were educated for prevention of thalassemia and haemoglobinopathies in $2007 .{ }^{10}$ In addition, a total 3600 health persons were educated on thalassemia prevention and therapy by NTES in 18 centres in 2009 and 2010.

According to reports of $\mathrm{MOH}, 46$ first level haemoglobinopathy diagnostic centres, 5 second level diagnosis and therapy centre and 5 third level prenatal diagnosis centre were licenced in 30 cities between 2003 and $2009 .^{8}$

In conclusion, premarital screening tests were $30 \%$ of all couples in 2003, it increased continuously during HPP and it reached $81 \%$ in 2008 . As a result there has been an $90 \%$ reduction in new affected births in Turkey.

\section{References}

1. Aksoy M, Lekin EW, Maurant AE, and Lehmann H. Blood groups, hemoglobins, and thalassemia in Southern Turkey and Eti Turks. Brit Med J. 1958;2:937.

2. Çavdar A0, Arcasoy A. The incidence of $\beta$ - thalassemia and abnormal hemoglobins in Turkey. Acta Hematol 1971;45:313-318.

3. Beksac MS, Gumruk F, Gurgey A, et al. Prenatal diagnosis of hemoglobinopathies in Hacettepe University, Turkey. Pediatr Hematol Oncol. 2011 Feb;28:51-5. Epub 2010 Sep 23.

4. Akar N, Çavdar A0, Dessi E, Loi A, Pirastu M, and Cao A. $\beta$-thalassemia mutations in the Turkish population. Journal of Medical Genetics1987;24:378-379.

5. Başak AN, Ozçelik H, Ozer A, et al. The molecular basis of $\beta$-thalassemia in Turkey. Hum Genet. 1992 May;89:315-8.

6. Canatan D, Kose MR, Ustundağ M, Haznedaroglu D, Ozbaş S. Hemoglobinopathy control program in Turkey. Community Genet, 2006,9:124-126.

7. Canatan D. Status of thalassemia and hemoglobinopathies in World and Turkey . (Editör: Canatan D) J Hem Onc- Special Topics 2010;3:1-4.

8. Ministry of Health. Mother and child heath general director. Hemoglobinopathy control program (Editör: Canatan D). J Hematol Oncol Special Topics 2010;3:5-8.

9. Altay Ç. Abnormal hemoglobins in Turkey. Turk J Haematol 2002; 19:63-74.

10. Canatan D, Aydinok Y, Kilinç Y, et al. National thalassemia prevention campaign: project of Talotir 11. International conference on thalassemia and hemoglobinopathies and 13th International TIF conference for thalassemia patients and parents. 8-11 October 2008, Singapore p:EPI27

11. Weatherall DJ. The inherited diseases of hemoglobin are an emerging global health burden. Blood. 2010 Jun 3;115:4331-6. Epub 2010 Mar 16.

12. Modell B and Darlison M. Global epidemiyology of hemoglobin disorders and derived service indicators. Bulltein of the World Health Organization DOI 10247/BLT 06.036673.04/03/2008.

13. WHO Guidelines for the control haemaoglobin disorders. WHO/HDP/GL 94.1 Control of hereditary diseases. WHO, Geneva. 1996.

14. Amato A, Grisanti P, Lerone M, et al. Prevention strategies for severe hemoglobinopathies in endemic and nonendemic immigration countries: the Latium example. Prenat Diagn. 2009 Dec;29: $1171-4$.

15. Cousens NE, Gaff CL, Metcalfe SA, Delatycki MB. Carrier screening for $\beta$-thalassaemia: a review of international practice.Eur J Hum Genet. 2010 0ct;18:1077-83. 